\title{
Teaching Production Écrite Débutante Using Interactive Quizziz Game Learning Media
}

\author{
Evi Eviyanti ${ }^{1}$, Isda Pramuniati ${ }^{2}$,Irwandy $^{3}$, Wahyuni Sa'dah ${ }^{4}$ \\ 1,2,3,4 French Language Education, Universitas Negeri Medan, Indonesia \\ eviko65@gmail.com,pramuniatiisda@gmail.com,irwandymanday@gmail.com, \\ wahyunisadah122@yahoo.com
}

\begin{abstract}
The Covid-19 pandemic forces a social distancing policy or in Indonesia it is better known as physical distancing to minimize the spread of Covid-19. Universitas Negeri Medan as one of the LPTKs responded with a policy of learning from home, through online learning with the use of information technology. The objectives of this study were to: (1) develop teaching materials based on Quizziz interactive game learning media in teaching Production Écrite Débutante, (2) assessing the feasibility of teaching materials based on Quizziz interactive game learning media in teaching Production Écrite Débutante. This development research uses the ADDIE (Analysis, Design, Development, Implementation, and Evaluation) development model. The research instrument used was a questionnaire and validation instruments for material experts and the design of teaching materials. Based on the results of the assessment by teaching material experts Production Écrite Débutante. Based on interactive game learning media Quizziz that was developed has content feasibility, namely the average score of $91.33 \%$.very good), the feasibility of presenting the average score of $94.54 \%$. (Very good), and the linguistic aspect obtained an average score of $94.61 \%$. (Very good).The average score of the expert's assessment of teaching material design obtained $85.9 \%$ (Good). Based on the results of the validation, it shows that the teaching materials Production Écrite Débutante which has been developed to meet the demands of learning needs. Researchers limit the problem to the process of developing teaching materials based on interactive quizziz game learning media in teaching Production Écrite Débutante.
\end{abstract}

Keywords physical activity; nutritional status; physical fitness

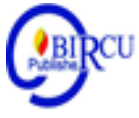

\section{Introduction}

Currently, the development of information and communication technology has provided a bright vehicle for the world of education. Through information and communication technology, education can develop by the demands of changing times.

E-learning is the use of information and communication technology to enable people to learn anytime and anywhere. (Dahiya,2012). The term e-learning has several meanings according to the current use of e-learning. E-learning has two types, namely synchronous and asynchronous. Synchronous means at the same time. The learning process occurs at the same time between lecturers and students online. Meanwhile, asynchronous means not at the same time. Students can take different learning times with lecturers who provide material. Asynchronous is popular in e-learning because students can access teaching 
materials anywhere and anytime. They can carry out the learning and finish it at any time according to the schedule set by the lecturer. Learning can take the form of text, animation, simulation, educational games, tests, quizzes, and assignments.

E-learning can fully immerse students in an atmosphere that is conducive to learning. At any time and in many places, e-learning can be accessed through the internet. Students can choose when and how much time to devote to a chosen subject's learning. Learners can easily match their everyday life with their learning activities. To engage in an e-learning program, they do not need to leave home and learning does not entail complicated logistics. A machine, Internet connection, and access to the internet are all the needs of a participant. Finally, e-learning materials are dynamic and can be adapted, upgraded, and modified to meet the needs of the learner. Activities can be added and integrated quickly. Nowadays the e-learning software can also be automatically updated by connecting to the server (Ivanescu, Barda, \& Vladicescu, 2008).

One of the media used is a computer network. The learning process like this can be carried out through learning, namely designing effective learning by considering and using various things optimally, such as choosing learning methods that are by the characteristics of the subject matter, creating attractive media, and utilizing the potential of students so that they can be involved in the learning process. Various terms are used to express opinions/ideas about electronic learning, including on-line learning, internet-enabled learning, virtual learning, or web-based learning. Furthermore, Priyanti, Santosa, and Dewi (2019) explained that interactive multimedia offers students the opportunity to actively engage in their learning. By offering user feedback and self-check activities, they can be motivated to think, communicate, and learn the importance of the material content.

The teaching and learning process based on e-learning has been carried out by every lecturer who teaches courses. However, in practice, there are several obstacles faced by lecturers and students, especially in the Production Écrite Avancée course. At each meeting for the teaching and learning process, the lecturer explains the material, provides exercises as a routine task using PowerPoint media and www.youtube.com. Then the teaching materials (books) in French "Tendances" used by the lecturer have not explained in detail the teaching materials needed by the lecturers to teach them to students. Although the book "Tendances" consists of a teaching manual for lecturers, teaching materials, exercises, and a CD (short "dialogue" video and audio).

E-learning that has been implemented by lecturers during WFH has not been able to motivate students to study the Production Écrite Avancée course. So that students' writing skills in French are still not good. This is supported based on the results of observations made by researchers during the implementation of online lectures shows that some writing errors that tend to be made by students, for example, conjugation of verbs, especially irregular verbs, and the accuracy of writing and using words are by the context of communication. Examples of some:

*Dans mon ville, tous le monde fait une voyage avec le transport en commun.
pré. adj.poss n.f, adj art.déf. nom verbe art.in nom pré. art.déf n.m pré. adj.

Within my city, all a world makes a trip with a public transportation

The meaning: In my city, everyone travels together by public transportation.

The sentence above is a sentence written by students to describe the means of transportation in the city where they live. When the sentence is translated into French, it can be seen that there are errors in the use of words, especially in words along with public 
transportation. In addition to the mistaken meanings of the translation from French to Indonesian, other errors can also be found in the sentence. For example, the phrase * 'mon ville', the word ville or city, in French is femina, so the word that should be used is 'ma' instead of 'mon', so the phrase becomes 'ma ville'. The use of the word 'faire une voyage' is also incorrect in the sentence, the first mistake is in the word 'une', which the word 'un' should have used because the word 'voyage' is a masculine noun. Then faire un voyage is a word which means a long journey or a long duration. If you are only traveling within one city, the word you should use is 'se déplacer'. Furthermore, there is an error in the use of the preposition 'avec', in French the word 'avec' means 'together with', this error occurs due to the influence of the mother tongue (Indonesian), which is that every time you say 'using a car' it is often said 'by car'. Based on correct French grammar, the preposition 'en' should be used instead of 'avec'. The last mistake is in the writing of the word tous le monde, according to the prevailing spelling in French, the phrase is never in the plural form 'tous', although when interpreted it means 'all'. The phrase should be written tout le monde.

Based on the explanation of the mistakes made by students, it can be seen that for writing one French sentence, the student has made 5 language errors. These errors include morphosyntax and word choice errors (lexical / orthography lexical).

All the mistakes that the students made were basic errors in French. The cause of these errors is imperfect knowledge and mastery of grammar and vocabulary possessed by students. Even though the student is already in the second year of study (semester IV). This means that they have studied French for 2 years in the French Language Education Study Program.

Based on the implementation of the online teaching and learning process, the teaching materials and media used the results of the midterm exams and some of the obstacles faced by lecturers and students. Therefore lecturers must make innovations in the teaching and learning process, especially teaching materials and online learning media by the development of industrial revolution 4.0 technology. This is done to motivate students to improve their French writing skills (Production Écrite). In line with research results Hanum (2013) about the standards of e-learning learning, namely:

"There must be an evaluation of teachers, students, content (materials, assignments, quizzes), processes (activeness, peer assessment), organizers (regulations, registration process procedures), implementation (facilities and technical support during e-learning). , material (compliance with the syllabus, ease of understanding, ease of access). "

Therefore, research on the development of teaching materials based on online learning media is important to do. Media is part of the learning component, the benefits and functions of media in learning are felt by both lecturers and students. The use of media in the teaching and learning process can generate new desires and interests, generate motivation and stimulation of learning activities, and even bring psychological influences on student choir participants (Tobing, 2020). The success of the media in improving the quality of student learning is determined by the ability of the lecturer to choose the media to be used in learning activities. The use of technology media provides benefits for teachers and students to access learning materials and interact directly in learning in the classroom, and also outside the classroom through online media (Prasasti, 2019). The role of the media in learning is not in doubt. A number of studies have shown that learning media has a significant effect in increasing motivation or interest, processes or activities, and learning outcomes (Siahaan, 2020). 
One of the game-based learning media that can be used as an evaluation to measure students' understanding of teaching Production Écrite to improve their French writing skills is Quizziz. Quizizz is a game-based educational application that can be used as a medium for evaluating learning activities in online learning. If the learning evaluation is carried out with text and read by the lecturer, it will be a tedious activity for students. Therefore, the use of varied learning media can be more attractive to students.

The Quizziz application is an interactive game that has various game features. One of its features is to train accuracy and ability and quick thinking power to write, especially in French. These features conform to the demands of French grammar and vocabulary writing.

Unlike other game applications, lecturers can create teaching materials and upload them to https://quizziz.com. The Quizizz application also has game characteristics such as avatars, themes, memes, and entertaining music in the learning process. Quizizz also allows students to compete with each other and motivate their learning so that learning outcomes in French can be improved. Students take the quiz at the same time in class and see their live ranking on the leaderboard. Lecturers can observe the process and download the results when the quiz is over to evaluate student performance. Quizizz can motivate student learning and improve their learning outcomes. Furthermore according to Irwan, et al (2019) that one of the interesting and interactive learning media that prioritizes cooperation, communication, and can lead to interaction between students is through games which have the characteristics of creating motivation in learning, namely fantasy, challenges, and curiosity. Here is the initial view of the Quizziz application and the features available on the Quizziz application.

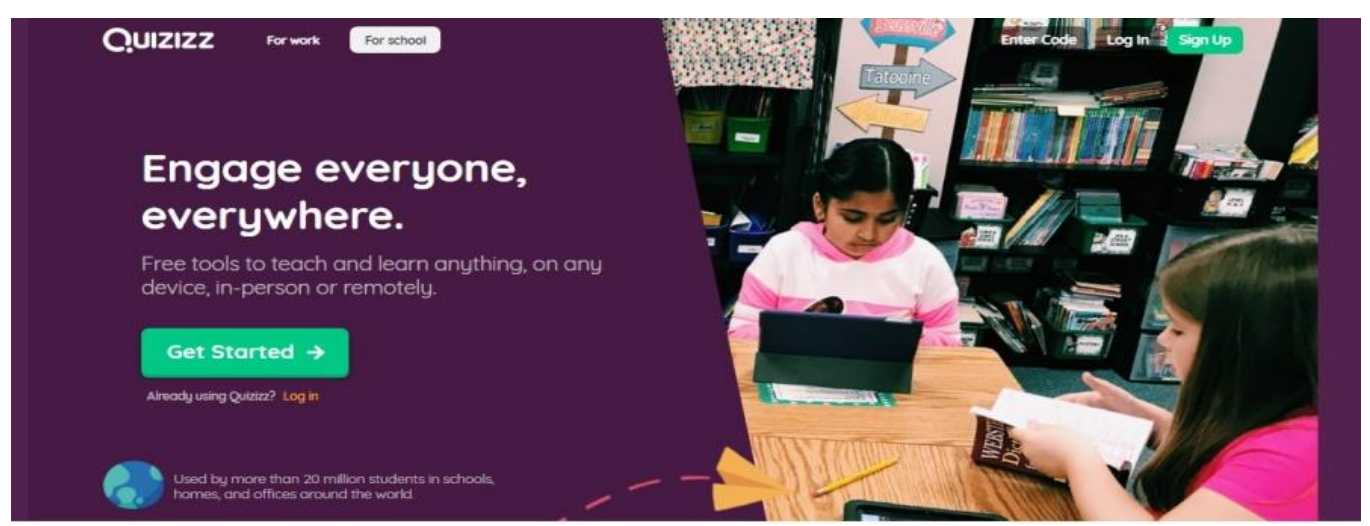

Figure 1. Quizziz Initial View

(Source: https://quizizz.com/)

Table 1. Features on Quizziz (https://quizizz.zendesk.com/)

\begin{tabular}{|c|l|l|}
\hline No. & \multicolumn{1}{|c|}{ Features } & \multicolumn{1}{c|}{ Function } \\
\hline 1 & Explore & $\begin{array}{l}\text { This feature is a page that contains a library of public quizzes that have } \\
\text { been created by other users. In this feature, users can search for the } \\
\text { quiz references they want based on the quiz name or the quiz maker } \\
\text { username. }\end{array}$ \\
\hline 2 & My Library & $\begin{array}{l}\text { This feature contains all the quizzes that have been created by users. } \\
\text { This feature also contains "Collections" which is a folder used to } \\
\text { organize quizzes. }\end{array}$ \\
\hline 3 & Reports & $\begin{array}{l}\text { This feature contains results reports for all quiz games that users } \\
\text { organize. }\end{array}$ \\
\hline 4 & Classes & $\begin{array}{l}\text { This feature allows users to be able to organize their students, can give } \\
\text { quizzes easily, and sort user reports by class. This feature can also } \\
\text { provide several other benefits, such as being able to schedule a } \\
\text { "homework" quiz according to user preferences, integration with }\end{array}$ \\
\hline
\end{tabular}




\begin{tabular}{|c|l|l|}
\hline & & Google Classroom and others. \\
\hline 5 & Memes & $\begin{array}{l}\text { In this feature, users can put meme images or funny pictures by } \\
\text { selecting the images provided or creating their own in the quiz that has } \\
\text { been made. }\end{array}$ \\
\hline 6 & Create & $\begin{array}{l}\text { This feature will take the user to the "Quiz Editor" where users can } \\
\text { create their own quizzes or lessons. }\end{array}$ \\
\hline
\end{tabular}

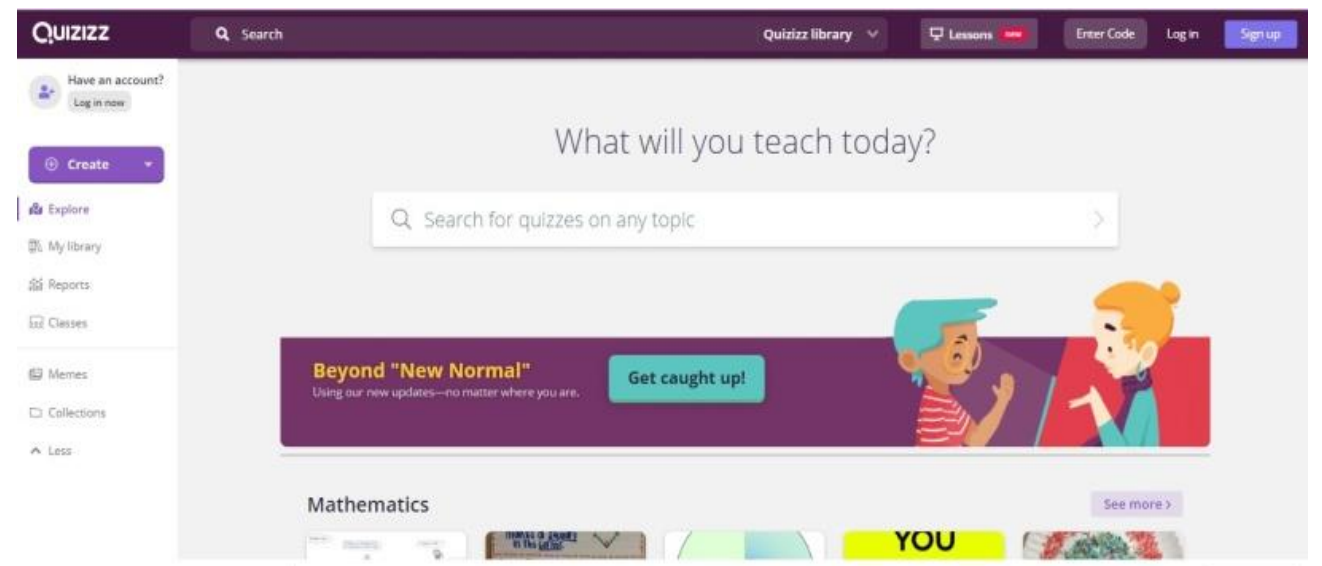

Figure 2. Display Features on Quizziz

There is a need to reconceptualize the mobile age with the latest applicable nature of technology and learning environment in 21st-century learning because students were handheld by technology.

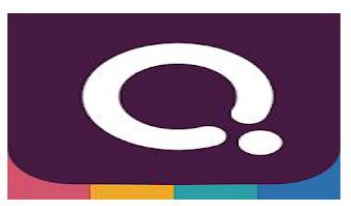

Quizizz: Mainkan untuk belajar

quizizz Inc. Pendidikan

$\star \star \star \star \star \star 77.543=$

$\sqrt{3+}$

Aplikasi ini kompatibel dengan perangkat Anda.

田 Tambahkan ke Wishlist
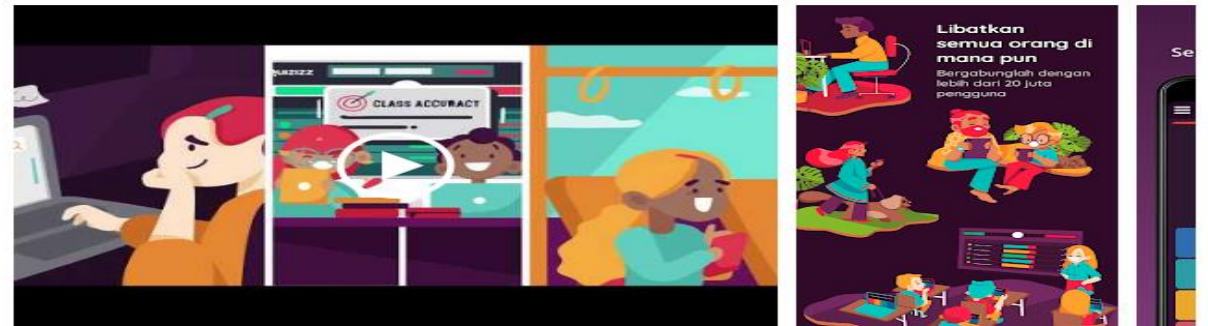

Figure 3. The display of the Quizziz Application on the Play Store

(Source: https://play.google.com/store/apps/details?id=com.quizizz_mobile)

When the lecturer will use the Quizziz application, the lecturer enters the site https://quizizz.com/. Then click the sign up. The lecturer signs up using his google account, or email. After successfully signing up, please click a teacher. Look at the following picture! 


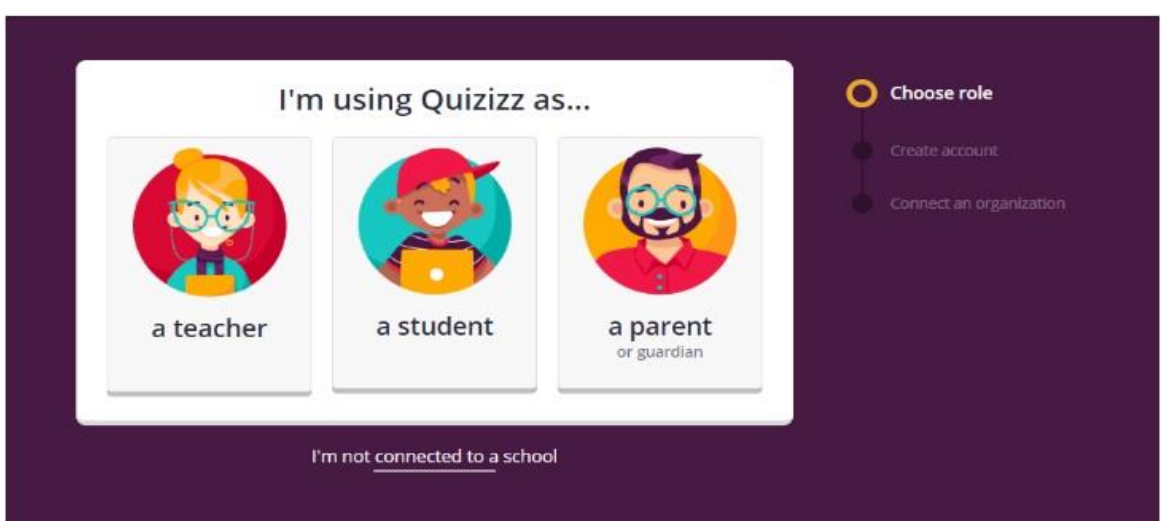

Figure 4. Display of account selection on Quizziz

(Source: https://quizizz.zendesk.com/)

Game-based learning can be done in 'live' mode in class or it can also be given as homework in 'homework' mode. This is very possible because Quizizz provides a timer; when the quiz will open and when will it end. Students only need to be given a pin game and they will still be able to study wherever they are. Students can also do this quiz either individually or in groups.

The advantage of quizizz is in the part of the process which adjusts to the speed of the student. Students will not be judged on how fast they answered questions. Besides, the scores can be downloaded in the form of excel documents, making it easier for lecturers to make assessments.

Zhao (2019) and Mei, Ju, and Adam, (2018) found that Quizziz had a positive impact on the learning process in the classroom where the scores obtained were higher and increased collaboration between students in group work. This is very positive and is considered to be a solution to the use of gadgets in class.

\section{Research Methods}

This research method is research and development. Research and development in education is a process used to develop and validate educational products, such as teaching materials or learning media.

This development research uses the ADDIE (Analysis, Design, Development, Implementation, Evaluation). The choice of this model is based on the consideration that this model is easy to understand. Also, this model is developed systematically referring to the theoretical foundation of the learning design being developed. This model is arranged programmatically with a systematic sequence of activities to solve learning problems related to learning media according to the needs and characteristics of students.

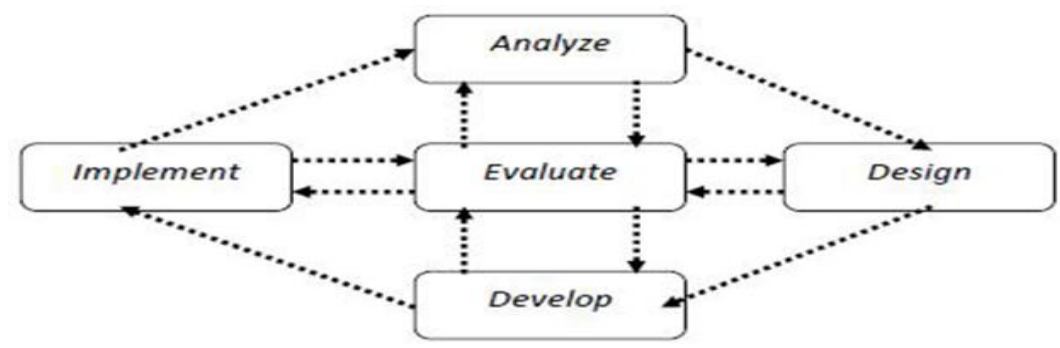

Figure 5. The ADDIE Development Model (Anglada, 2007) 
The research stages were carried out as follows: 1) analysis is a process of defining what students will learn, namely identifying problems, needs assessment, 2) design includes program structure preparation, storyboarding, interface design, material presentation systematics, illustration, visualization, and tool design, evaluation, 3) development, researchers collect material, manufacture, test, and distribution, develop product evaluation instruments, evaluate experts materials, media and learning designs, product improvements based on advice from experts, 4) implementation, validated teaching materials (teaching and training materials) uploaded to https://quizziz.com. Furthermore, instructional materials based on instructional media game interactive quizziz are used on the Production Écrite Débutante teaching and 5) evaluation, the researcher will evaluate (posttest) the learning outcomes of the Production Écrite Débutante study to determine the effectiveness of the teaching materials. In this study, researchers researched the implementation stage.

The research instrument used in this study was a questionnaire that needs analysis and validator assessment sheets. While the research data source is answers to the student needs analysis questionnaire and the results of the assessment of teaching materials from the validator.

The data collection techniques used in this study are as follows:

1) Making a student needs analysis questionnaire

2) Analyzing the results of the student's questionnaire answers

3) Designing teaching materials Production Écrite Débutante following the Semester Lesson Plan,

4) Validation of Production Écrite Débutante teaching materials.

\subsection{Data Analysis Technique}

This data was collected through expert validation, a questionnaire given to students. The assessment instrument for material expert validators and design experts is made in the form of a Likert scale which has been given a score as in table 1 below.

Table 1. Criteria for Answers to Validation Instruments with a Likert Scale

\begin{tabular}{|c|c|c|}
\hline No. & Answer & Score \\
\hline 1 & Very good & 4 \\
\hline 2 & Good & 3 \\
\hline 3 & Not good & 2 \\
\hline 4 & Not good & 1 \\
\hline
\end{tabular}

(Sugiyono, 2013)

Then the data were analyzed descriptively quantitatively, namely calculating the percentage of indicators for each category of reading material in the form of handouts.

Based on the results of the calculation according to the formula above, a percentage is generated. Then the score classification is changed to a classification in the form of a percentage (Sugiyono, 2013). The percentage results are interpreted using the qualitative sentences listed in table 2 below.

$$
\text { Score Percentage }=\frac{\text { Number of jndicatora per category }}{\text { Numbe } \text { of indicat ora per cat egory }} \times 100 \%
$$

Table 2. Criteria for the Percentage of Indicators on Materials Teach Learning Media Based Jeu Interractive Quizziz At the Production Écrite Débutante Teaching

\begin{tabular}{|c|c|c|}
\hline No. & Answer & Score \\
\hline
\end{tabular}




\begin{tabular}{|c|c|c|}
\hline A & Very good & $81 \% \leq \mathrm{X}<100 \%$ \\
\hline B & Good & $61 \% \leq \mathrm{X}<80 \%$ \\
\hline C & Moderate & $41 \% \leq \mathrm{X}<60 \%$ \\
\hline D & Not good & $21 \% \leq \mathrm{X}<40 \%$ \\
\hline E & Not very good & $0 \% \leq \mathrm{X}<20 \%$ \\
\hline
\end{tabular}

(Sugiyono, 2013)

\section{Results and Discussion}

\subsection{Results}

a. Analysis

Needs analysis was conducted to determine student interest in media in internetbased learning (e-learning). This is done to identify and clarify problems that occur during the teaching and learning process and improving learning media. The needs analysis stage is a step needed to determine the appropriate form of e-learning media and in accordance with the needs of students in teaching the Production Écrite Débutante course.

The results of the needs analysis obtained through a questionnaire using google form were given to 55 first semester students of the 2020/2021 academic year French Language Education Study Program, Medan State University as follows:

Table 3. Student Needs Analysis

\begin{tabular}{|c|c|c|}
\hline No. & Statement & Answer \\
\hline 1. & $\begin{array}{l}\text { According to brothers, courses } \\
\text { Production Écrite Débutante } \\
\text { need to be studiting) } \\
\text { ny students? }\end{array}$ & $\begin{array}{l}\text { Of the } 55 \text { students, } 100 \% \text { agreed that Production } \\
\text { Écrite Débutante needed to be studied. }\end{array}$ \\
\hline 2. & $\begin{array}{l}\text { The purpose of studying the course } \\
\text { Production Écrite Débutante } \\
\text { a. write b. other }\end{array}$ & $\begin{array}{l}\text { Of the } 55 \text { students, } 50 \% \text { answered that the objective } \\
\text { of studying the Production Écrite Débutante course } \\
\text { was to write and } 12 \% \text { answered others. }\end{array}$ \\
\hline 3. & $\begin{array}{l}\text { In my opinion, teaching Production } \\
\text { Écrite Débutante must use interesting } \\
\text { learning media so as not to be boring }\end{array}$ & $\begin{array}{l}\text { Of the } 55 \text { students, } 100 \% \text { agreed that Production } \\
\text { Écrite Débutante's teaching must use interesting } \\
\text { learning media. }\end{array}$ \\
\hline 4. & $\begin{array}{l}\text { E-learning based learning media is more } \\
\text { attractive than other learning media } \\
\text { (adobe flash, power point, image media) }\end{array}$ & $\begin{array}{l}\text { Of the } 55 \text { students, } 71 \% \text { agreed and } 29 \% \text { did not } \\
\text { agree that e-learning based learning media were more } \\
\text { attractive. }\end{array}$ \\
\hline 5. & $\begin{array}{l}\text { Do you know about the Jeu Interractive } \\
\text { Quizziz-based e-learning media? }\end{array}$ & Of the 55 students, $59.7 \%$ knew and $40.3 \%$ did not \\
\hline
\end{tabular}




\begin{tabular}{|c|c|c|}
\hline No. & Statement & Answer \\
\hline & & $\begin{array}{l}\text { know about the Jeu Interractive Quizziz learning } \\
\text { media. }\end{array}$ \\
\hline 6. & $\begin{array}{l}\text { If your answer is "yes", you get } \\
\text { information about the Jeu Interractive } \\
\text { Quizziz learning media from: } \\
\text { a. lecturer, b. friends, c. Internet }\end{array}$ & $\begin{array}{l}\text { From } 55 \text { students, } 51.6 \% \text { obtained information about } \\
\text { Jeu Interractive Quizziz learning media, } 9.7 \% \text { friends } \\
\text { and } 38.7 \% \text { internet. }\end{array}$ \\
\hline 7. & $\begin{array}{l}\text { Teaching Production Écrite Débutante } \\
\text { using the Jeu Interractive Quizziz learning } \\
\text { media can motivate students to improve } \\
\text { their writing skills in French. }\end{array}$ & $\begin{array}{l}\text { Of the } 55 \text { students, } 96.8 \% \text { agreed that the Jeu } \\
\text { Interractive Quizziz learning media could motivate } \\
\text { students. }\end{array}$ \\
\hline
\end{tabular}

\section{b. Design}

At this stage, the researcher makes a Semester Learning Plan (RPS) for the course Production Écrite Débutante (Online) which is taught to students in semester 1 of the 2020/2021 academic year.

\section{c. Development}

Researchers make teaching materials Production Écrite Débutante corresponding RPS to upload to https://quizziz.com. But before teaching materials, Production Écrite Débutante must go through the validation stage to get a product that is suitable for use in teaching Production Écrite Débutante.

\section{d. Implementation}

After the Production Écrite Débutante teaching materials were validated and revised. Then the teaching materials are uploaded to https://quizziz.com and used in Teaching Production Écrite Débutante.

On this occasion, the research was carried out until the implementation stage: the implementation of Production Écrite Débutante teaching materials based on Quizziz game learning media.

\section{e. Data on the Validation Results of the Material Expert Team}

The feasibility of teaching materials is validated by material experts and design experts. After being validated by experts, the research product was tested in a limited field group and revisions were made to determine the feasibility of the Production Écrite Débutante teaching materials.

The results of validation and assessment by material experts on each aspect of the overall assessment are determined by the average score of each criterion. The results of the assessment were analyzed to determine whether or not the Production Écrite Débutante teaching materials were appropriate. The average percentage of the results of the assessment by material experts is assessed based on the following four aspects of the assessment: content feasibility, presentation feasibility, language feasibility, and book worthiness.

Based on the results of the assessment of the feasibility aspect of the content of the material, the Production Écrite Débutante teaching material is declared "Very Good" with an average total percentage of $91.33 \%$. 


$$
\text { Percentage }=\frac{137}{15 \times 10} \times 100 \%=91.33 \%
$$

The percentage of the content feasibility score by the material expert is very valid, so the content of the teaching material Production Écrite Débutante developed need not be revised.

Based on the results of validation by material experts on the feasibility of presenting teaching materials Production Écrite Débutante developed, the acquisition percentage score was $94.54 \%$. The percentage is obtained from the calculation:

$$
\text { Percentage }=\frac{104}{11 \times 10} \times 100 \%=94.54 \%
$$

The percentage of the feasibility score for the presentation of teaching materials Production Écrite Débutante by the material expert the qualifications are very valid so that the feasibility of their presentation does not need to be revised.

Based on the results of validation by material experts on the percentage of language eligibility scores on teaching materials Production Écrite Débutante developed, obtained a score of $94.61 \%$. The percentage is obtained from the calculation:

$$
\text { Percentage }=\frac{123}{13 \times 10} \times 100 \%=94.61 \%
$$

The percentage of the language eligibility score by the material expert on the qualifications is very good, so that the language feasibility of the teaching material Production Écrite Débutante developed need not be revised.

In addition to grading, experts also provide input in the form of comments and suggestions related to the aspects assessed in the teaching materials Production Écrite Débutante.

Table 4. Revised List of Material Experts

\begin{tabular}{|c|l|}
\hline Validation Aspects & \multicolumn{1}{c|}{ Revision } \\
\hline \multirow{2}{*}{ Theory } & 1. Turn your foreword into a foreword \\
\cline { 2 - 2 } & 2. Improve the writing system \\
\hline
\end{tabular}

All comments and suggestions given by the validator are used as consideration in making revisions to teaching materials Production Écrite Débutante that was developed.

\section{f. Data Validation Results Design Expert Team}

Design experts have validated the Production Écrite Débutante teaching materials product. The assessment on this aspect of the design was carried out to improve the appearance quality of Production Écrite Débutante teaching materials.

Based on the eligibility criteria for learning design products, the scores obtained in the validation of the learning design obtained an average value of as much $85.9 \%$ on the Good criteria. These criteria indicate that the learning design product in the development of Production Écrite Débutante teaching materials is worth trying out in the learning process. 
Table 5. Assessment of Design Experts

\begin{tabular}{|c|c|c|c|}
\hline No. & Sub Component of Assessment & Average Score & Criteria \\
\hline 1 & The size of the teaching material & 89.20 & Good \\
\hline 2 & $\begin{array}{c}\text { Cover design teaching materials } \\
\text { (cover) }\end{array}$ & 83.90 & Good \\
\hline 3 & Design content of teaching materials & 84.50 & Good \\
\hline \multicolumn{2}{|c|}{ Average } & $\mathbf{8 5 . 9 0}$ & Good \\
\hline
\end{tabular}

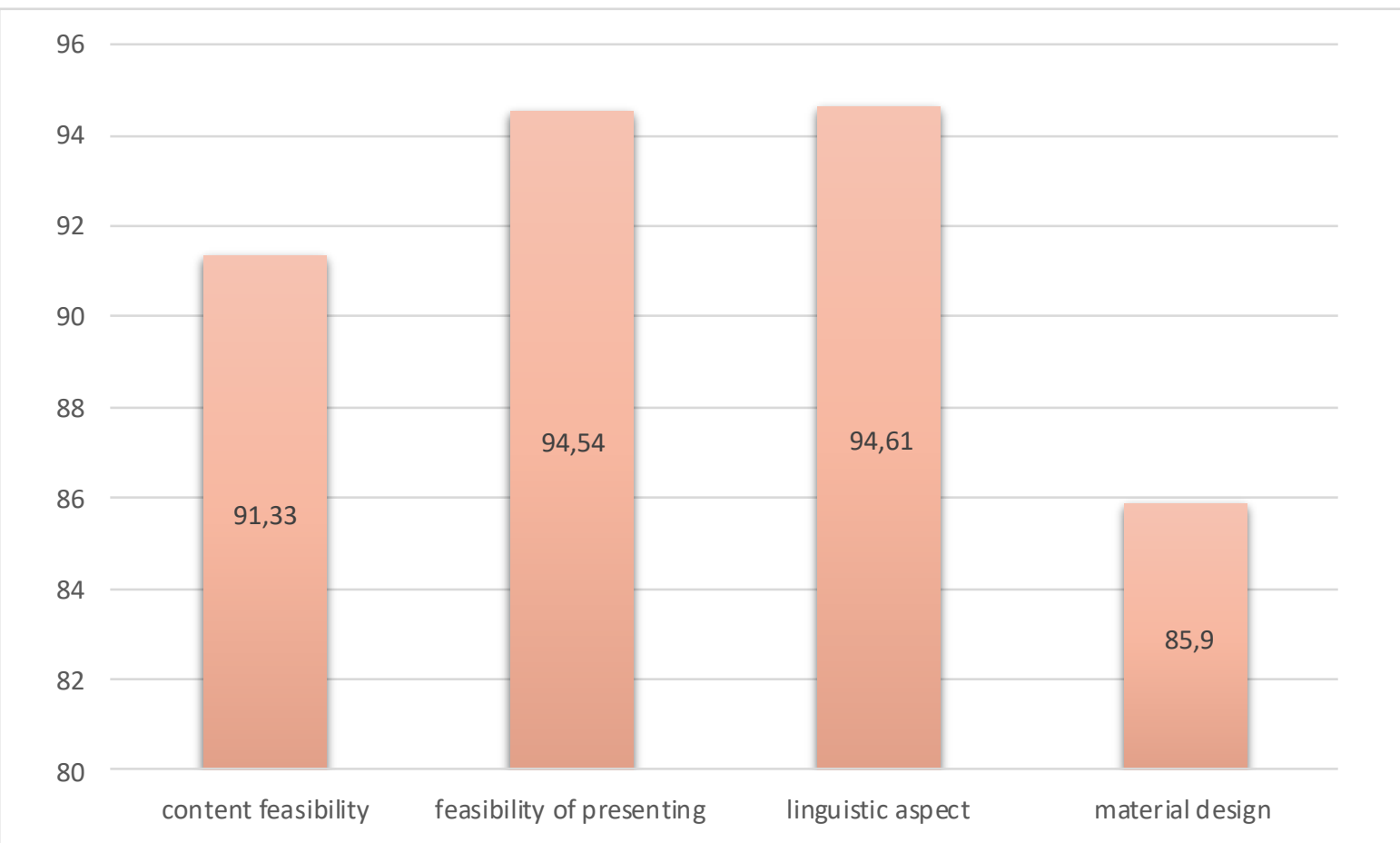

Figure 6. The results of the Assessment by Teaching Material Experts Production Écrite Débutante

Based on the results of the assessment by teaching material experts Production Écrite Débutante. Based on interactive game learning media Quizziz that was developed has content feasibility, namely the average score of $91.33 \%$. Very good), the feasibility of presenting the average score of $94.54 \%$ (very good), and the linguistic aspect obtained an average score of $94.61 \%$ (very good). The average score of the expert's assessment of teaching material design obtained $85.9 \%$ (Good). Based on the results of the validation, it shows that the teaching materials Production Écrite Débutante. Which has been developed to meet the demands of learning needs.

\subsection{Discussion}

The nature of technology itself should be implemented into the learning process that is intended to make the Fourth Technological Revolution face the knowledge of the students. However, the truth is that most students in Indonesia, in particular, are still struggling to master the French language as their foreign language.

Based on the results of the needs analysis questionnaire that has been given to 55 first semester students, it shows that 1)100\% of students agree that the Production Écrite Débutante teaching must use interesting learning media, 2) .71\% of students agree and $29 \%$ do not agree that e-learning based learning media is more attractive, 3) $59.7 \%$ of students know and $40.3 \%$ do not know about learning media Jeu Interractive Quizziz, and 
4) $96.8 \%$ of students agree that Jeu Interractive Quizziz learning media can motivate students. This data shows that in general students expect lecturers who teach the Production Écrite Débutante course to be able to use interesting internet-based learning media and can motivate them, for example, the Quizziz interactive jeu learning media. This is by the results of research conducted by Mei, Ju, Adam (2018) that according to high total no of a percentage of the positive point against using the game Quizizz during the Arabic class, the researchers found that using Quizizz during the Arabic class is importantly applicable in UPSI or another institute as a teaching method to make students more interesting and more focusing on the class. Amalia (2020) states that in English teaching and learning, there are many benefits of using Quizziz. Using Quizziz will add motivation to activities in the classroom and stimulate the interest of students in the material being taught. Furthermore, Zhao (2019) argues that students accept that Quizziz is simple to use it is enjoyable to use Quizziz to do in-class exercises, to help them study the materials of the course, and to stimulate their interest in studying accounting. They like this app's features especially the leaderboard, which shows their performance's live ranking and motivates them to study.Based on the results of this study, it has been proven that the use of interactive Quizziz learning media used in several fields of science (Arabic, English, and Accounting) is able to motivate student learning. Not many lecturers have used it Quizziz's interactive jeu learning media in teaching French.

Therefore, there are still very limited materials and exercises in the field of French that have been made by other users in the Quizziz application.

The products produced in this study are teaching materials Production Écrite Débutante according to the RPS. Next, teaching materials Production Écrite Débutante Quizziz's validated and revised Jeu interactive learning media-based learning media can be used in teaching Production Écrite Débutante.

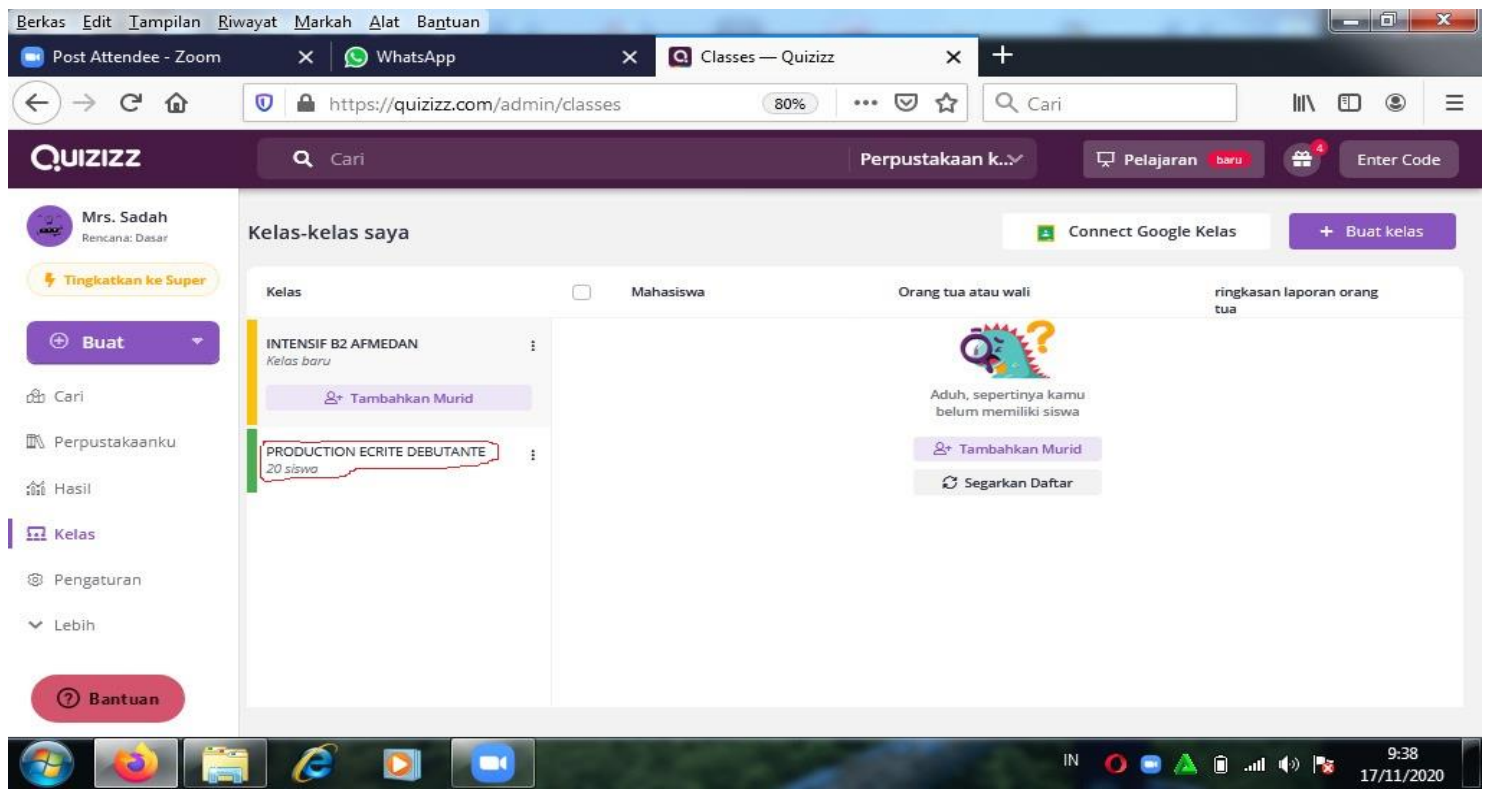

Figure 6. Quizziz Main Screen Display on a Lecturer Account 


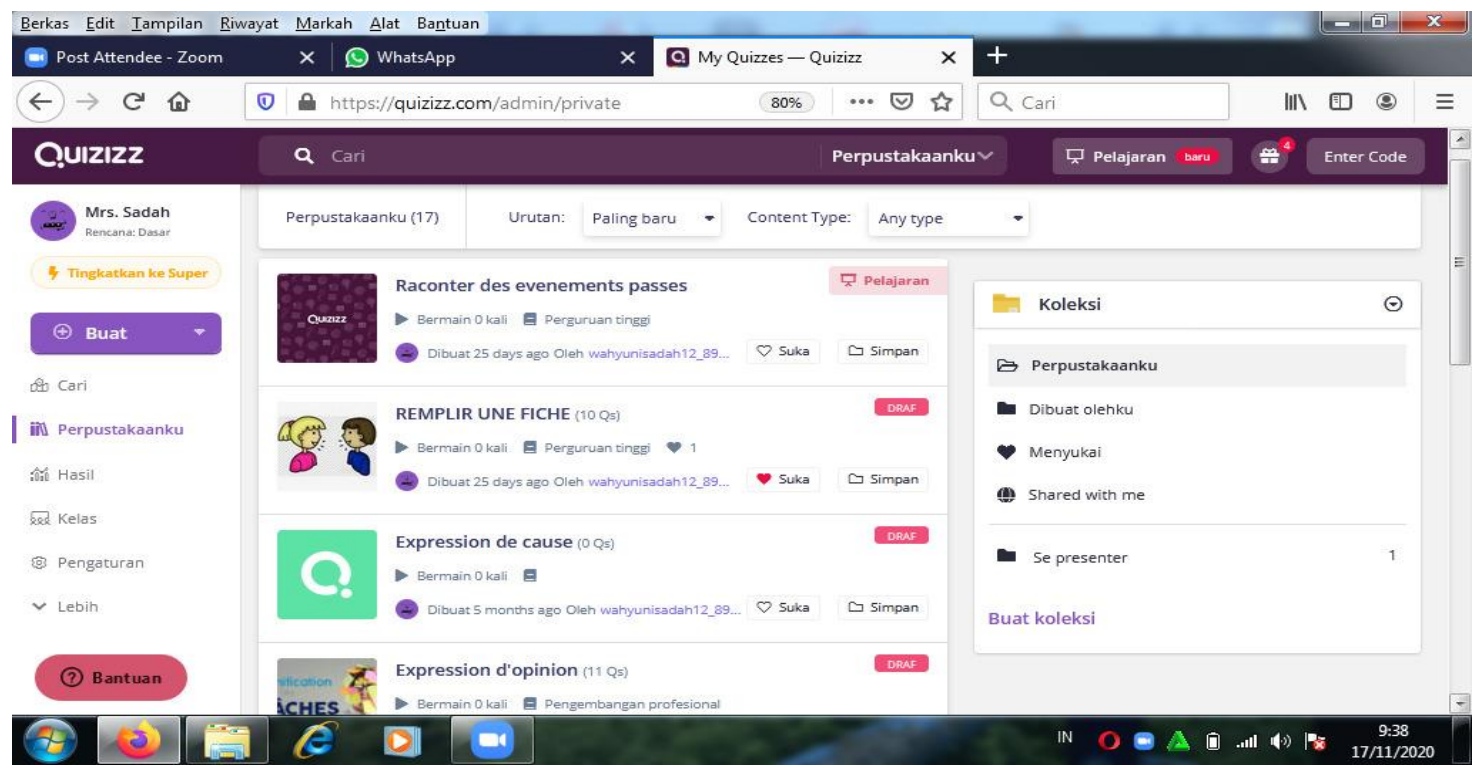

Figure 7. Topics of Teaching Materials Uploaded to Quizziz

Before the learning activities began, the lecturer explained about the interactive Quizziz game learning media used in the Production Écrite Débutante teaching.

As the platform of online game-based learning for this study, the online game called "Quizziz (https:/quizziz.com/admin?q=undefined\#) was launched." Each student was played by their smart phone, PC, or laptop, and enter the game with Pin no that is already ready by game, the lecturer must ensure that each of them has already joined with pin no that has been given.

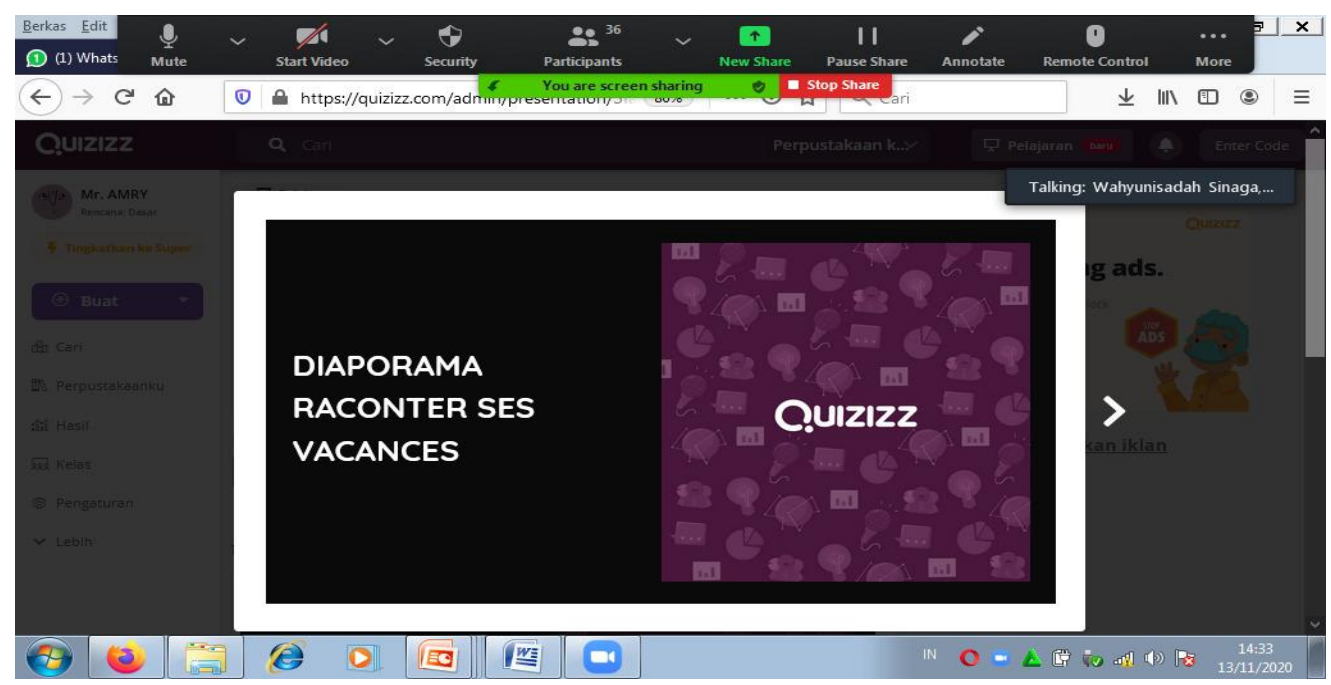

Figure 8. Topics of Teaching Materials Uploaded to Quizziz

The lecturer explains the teaching material according to what has been displayed on the interactive Quizziz game learning media using Zoom meetings. After that, the lecturer gave practice questions that had to be done by students. 

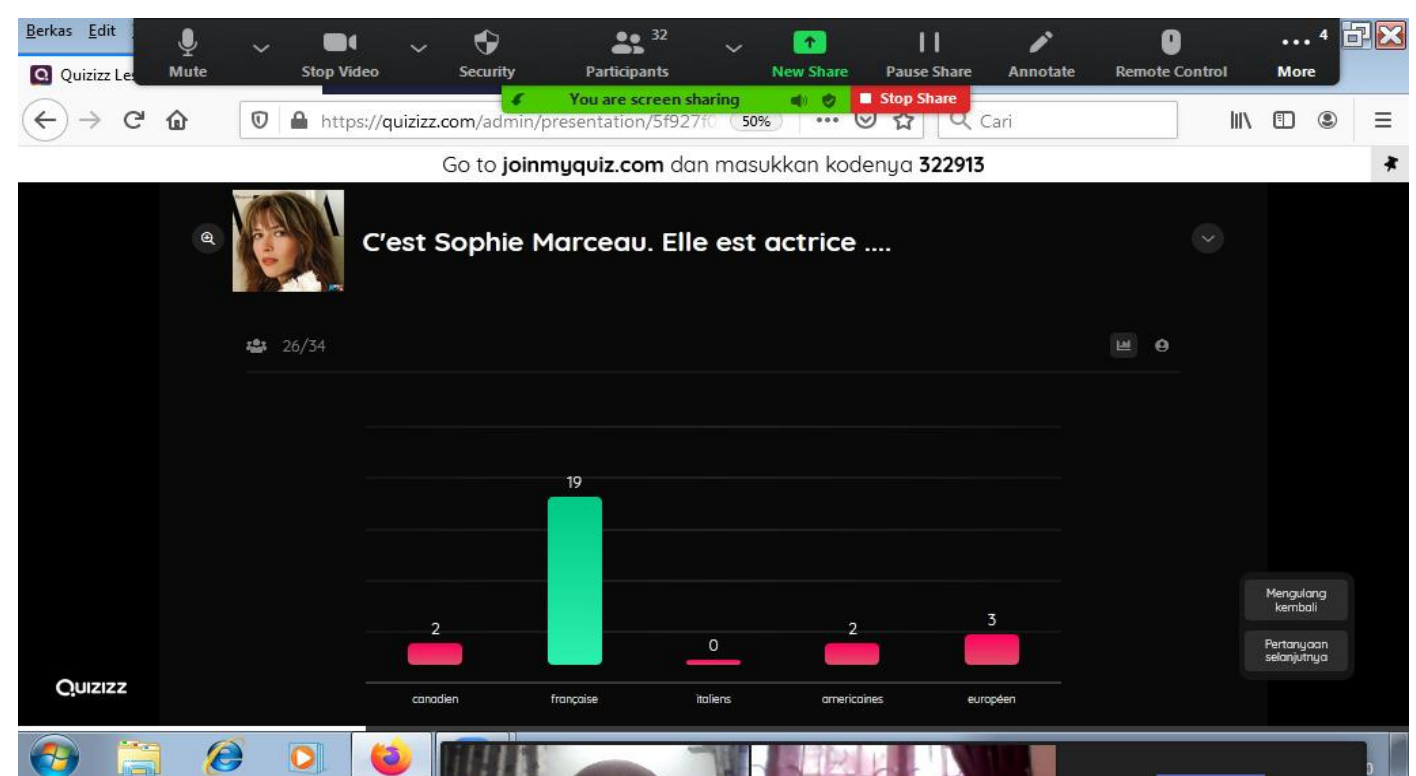

Figure 9. Examples of Exercises Uploaded to Quizziz

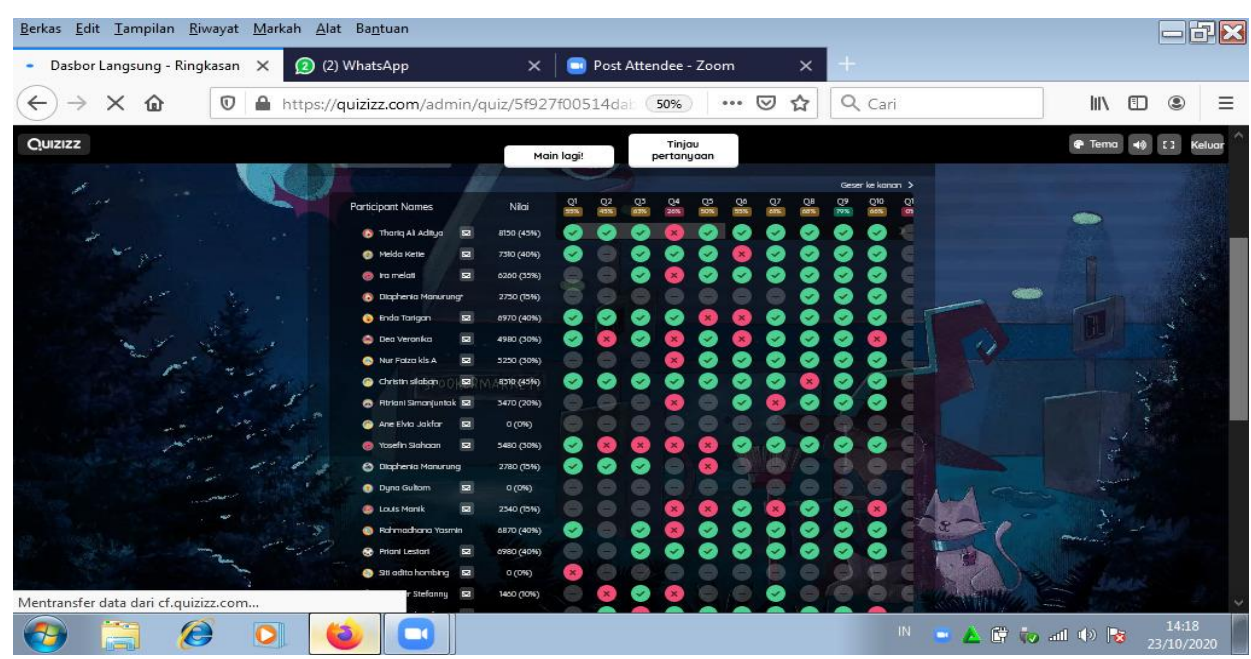

Figure 10. Display of Students Who Have Answered the Exercise

The game "Quizziz" allowed them to be more interested in participating. With Quizziz, when they finish answering a question, players do not have to wait for the whole class before they proceed to the next one. If after each question you prefer to stop, then Kahoot is better. After each question, you should pause and discuss, instantly confirming the understanding. With Quizziz, player's complete questions at their own rate, restricting all conversation to after all questions have been answered. (Medvedovska, Skarlupina, Turchyna, 2016).

Next Purba (2019) said Quizizz is a game-based educational application that brings multiplayer activities to the classroom and makes classroom learning more fun and more interactive. Media Quizizz has the advantage that the questions submitted have a time limit. Students are taught to be able to think ideally and quickly in solving problems contained in the interactive Quizizz game learning media. Another advantage found in the interactive game learning media Quizizz is that the answers to existing questions will be displayed in colors and images and appear on the lecturer's computer (as an operator) and student devices will change automatically based on the order of the questions presented. 


\section{Conclusion}

Applying educational technology develops abilities and cognitive features. Continuous use of the applications will assist students in improving their success in their studies, highlighting a much more optimistic overall education mindset. New technology is increasingly growing in application and production and the question is whether. To keep up with them, teachers are educated. Based on the results of the research, it shows that the teaching materials Production Écrite Débutante. Which has been developed to meet the demands of learning needs.

In general, students are happy and motivated to take part in the teaching Production Écrite Débutante using interactive Quizziz game learning media.

\section{References}

Amalia, Dinda Firly. Quizizz Website as an Online Assessment for English Teaching and Learning: Students' Perspectives. Jo-ELT (Journal of English Language Teaching) Fakultas Pendidikan Bahasa dan Seni Program Studi Pendidikan Bahasa Inggris IKIP http://ojs.ikipmataram.ac.id/index.php/joelt. June 2020, Vol.7 No.1 online: 2548-5865 print: 2355-0309 pp.1-8 doi:10.33394/jo-elt.v7i1.2638. (Diakses tanggal 12 November 2020).

Anglada, D. (2007).An Introduction to Instructional Design: Utilizing a Basic Design Model. http://www.pace.edu/ctlt/newsletter .Diakses pada tanggal 15 Mei 2019,

Dahiya, S., Jaggi, S., Chaturvedi, K.K., Bhardwaj, A., Goyal, R.C. and Varghese, C., 2016. An e-Learning System for Agricultural Education. Indian Research Journal of Extension Education, 12(3), pp.132-135.

Hanum, Numiek Sulistyo. 2013. Keefektifan E-Learning Sebagai Media Pembelajaran (Studi Evaluasi Model Pembelajaran E-Learning SMK Telkom Sandhy Putra Purwokerto). Jurnal pendidikan Vokasi. UNY.

Irwan, I., Luthfi, Z. F., \& Waldi, A. (2019). Efektifitas Penggunaan Kahoot! Untuk Meningkatkan Hasil Belajar Siswa [Effectiveness of Using Kahoot! to Improve Student Learning Outcomes]. PEDAGOGIA: Jurnal Pendidikan, 8(1), 95.

Ivanescu, Andrei, Barda, Ioana, Popenţiu Vladicescu, Florin. 2008. Distance Learning Answering Students'needs The Example Of The Interactive E-Learning Environment (IELE).The4th International Scientific Conference eLearning and Software for Education, Bucharest, April 17-18,2008.

Medvedovska, Darya. Skarlupina, Yulia. Turchyna, Tamar.a Integrating online educational Applications in the classroom/Medvedovska D., Skarlupina Y., Turchina T.//European Humanities Studies: $\quad$ State and Society, № 4 (2016). - Slupsk, Poland. C. 145-156

Mei, S., Ju, S., \& Adam, Z. (2018). Implementing Quizizz as Game Based Learning in the Arabic Classroom. European Journal of Social Sciences Education and Research, 12(1), 208. Doi: 10.26417/ejser.v12i1.p208-212

Prasasti, T.I., Solin, M., and Hadi, W. (2019). The Effectiveness of Learning Media Folklore Text of North Sumatera Based on Blended Learning by 10th Grade Students of Vocational High SchoolHarapan Mekar-1 Medan. Budapest International Research and Critics in Linguistics and Education (BirLE) Journal Vol 2 (4): 480490.

Priyanti, N.W.I., Santosa, M.H., Dewi, K.S... Effect of Quizizz towards the EleventhGrade English Students' Reading Comprehension in Mobile Learning Context. LEJU, Vol. 2 No. 2, July 2019 ISSN: 2613-9529. Universitas Pendidikan Ganesha, 
Singaraja, Indonesia.

Purba, L. S. L. (2019). Peningkatan Konsentrasi Belajar Mahasiswa Melalui Pemanfaatan Evaluasi Pembelajaran Quizizz Pada Mata Kuliah Kimia Fisika I. Jurnal Dinamika Pendidikan, 12(1), 29.

Siahaan, R.Y.K.P., Daulay, S., and Hadi, W. (2020). The Effectiveness of Public Speaking Learning Media Based on Digital Multimodal in Indonesian Language Courses at Politeknik Pariwisata Medan. Budapest International Research and Critics in Linguistics and Education (BirLE) Journal Vol 3 (4): 2036-2047.

Srimathi, H., Srivatsa, S.K. Knowledge Representation in Personalized E-Learning. Academic Open Internet Journal, Volume 23, 2008, ISSN 13114360.www.acadjournal.com

Sugiyono, 2013. Metode Penelitian Pendidikan: Pendekatan Kuantitatif, Kualitatif dan R \& D. Bandung: Alfabeta.

Tobing, O., Silitonga, P.H., and Gulo, N.L.F. (2020). The Utilization of Candle Media to Improve Breathing Engineering on Solfeggio Choir Universitas Negeri Medan. Budapest International Research and Critics in Linguistics and Education (BirLE) Journal Vol 3 (4): 2048-2055.

Zhao, F., (2019). Using Quizizz to Integrate Fun Multiplayer Activity in the Accounting Classroom. International Journal of Higher Education. Vol. 8, No. 1; 2019. doi:10.5430/ijhe.v8n1p37

https://play.google.com/store/apps/details?id=com.quizizz_mobilehttps://quizizz.com/admi n.

https://quizizz.com/admin/private

https://quizizz.zendesk.com. 